Ethiopian Journal of Environmental Studies \& Management 9(6): 793 - 803, 2016.

ISSN:1998-0507

doi: http://dx.doi.org/10.4314/ejesm.v9i6.11

Submitted: August 31, 2016

Accepted: November 11, 2016

\title{
WILLINGNESS TO PAY FOR IMPROVED SOLID WASTE MANAGEMENT SERVICES IN AN URBANIZING AREA IN SOUTH-EAST NIGERIA
}

\author{
*OYAWOLE, F.P., ${ }^{1}$ AJAYI, 0.P.,2 ${ }^{2}$ AMINU, R.0.1 ${ }^{1}$ AND AKERELE, D. ${ }^{1}$ \\ ${ }^{1}$ Department of Agricultural Economics and Farm Management, Federal University of \\ Agriculture, Abeokuta, Nigeria \\ ${ }^{2}$ School of Geography and Archaeological studies, University of the Witwatersrand, \\ Johannesburg, South Africa
}

\begin{abstract}
Developing countries often fail to pay adequate attention to solid waste management in the bid to accelerate the rate of their development, and this oversight typically culminates into an adverse impact on the environment and on public health and safety. This paper sought to analyse the factors influencing residents' willingness to pay for improved solid waste management services due to private sector involvement in Ihiala, Southeastern Nigeria. Data were collected with structured questionnaires administered to ninety respondents, and was analysed using descriptive statistics and ordered logit regression. The results showed that majority (92.2\%) of the residents were aware of the inherent risks that could stem out of improper solid waste management, although a lesser proportion of them (64.4\%) were willing to pay for an improvement. WTP was influenced by marital status, household size and income. It was recommended that government pursue policies that will significantly improve the income of residents and encourage public-private partnership in waste management.
\end{abstract}

Key Words: Solid waste management, Willingness to Pay, Ordered logit, pollution

\section{Introduction}

Municipal solid waste (MSW) is a term usually applied to a heterogeneous collection of wastes produced in urban areas, the nature of which varies from region to region (UNEP, 2005). It typically includes refuse from households, non-hazardous solid waste from industrial and commercial establishments, and refuse generated from institutions, markets, yards and street sweepings (Cointreaus-Levine,
1994). Inadequate municipal solid waste management is one major source of threat to human and environmental health, and a limiting factor to sustainable development efforts worldwide. Although many developing countries are intensifying efforts to accelerate the rate of their economic growth and development, the issue of solid waste management appears to be given less prominent attention in the economic advancement process. This raises a

*Corresponding Author: Oyawole, F.P.

Email: peteniy@gmail.com 
Willingness to Pay for Improved Solid Waste Management Services.................OYAWOLE et al.

primal question of whether concerns for improved solid waste management/disposal services is germane, especially in urbanizing areas of developing countries which are rapidly growing in terms of population, industries, economic activities and solid waste generation coupled with inadequate infrastructure.

The adverse effects of improper solid waste disposal are humongous, leading among others, to contamination of the atmosphere, soil and water, leading to health problems for the human and animal population. Various studies have shown that dumpsites provide food and shelter for rodents, insects and other vectors which transmits disease causing microbes to humans, thereby causing a whole lot of avoidable diseases (amoebic and bacillary dysenteries, typhoid fever, salmonellosis, cholera, yellow fever, and more recently, Lassa fever) and huge health care expenses (Alabi, 2004; Asase et al., 2009; UNEP, 2005).

The collection, transport, treatment, and disposal of solid wastes, have become a relatively difficult problem to solve for those responsible for their management especially in large cities and growing urban areas of developing countries. The problem is even more acute in many developing countries, where financial, human, and other critical resources generally are scarce (UNEP, 2005). Nigerian cities have been described as some of the dirtiest, the most unsanitary and the least aesthetically pleasing in the world (Adedibu, 1983; Alabi, 2004; Momodu et al., 2011). This is evidenced by the indiscriminate discharge of garbage into drains and the highways. Approximately 75 percent of solid waste collected in most Nigerian cities is disposed in open dumpsites, which are poorly maintained, and are also a source of pollution and a cause of poor urban aesthetics (CASSAD, 1998; Yusuf et al., 2007).

Waste management services in Nigeria are mainly confined to the government with a number of agencies charged with its execution at the three tiers of government. This attitude stems in part from the belief that environmental degradation with urban solid waste generation is an inevitable price of development (Chukwu, 2010; Salau, 1992; UNEP, 2005). However, their ability to curtail the problems of waste collection deteriorates with time, due to rising capital costs of plant and equipment, as well as increasing operation and maintenance costs. It has become apparent that private sector participation in SWD is inevitable especially with the current dwindling government income, inclination towards tighter budgets, as well as rapid spatial and population growth of most urban areas and the corresponding increase in level of waste generated.

This is because where existing public service delivery are typically inadequate, private sector participation offers a means of enhancing efficiency through the introduction of commercial principles and greater attention to customer satisfaction. Furthermore, in situations where local public funds for investment are in chronically short supply, the private sector may be able to mobilize needed investment funds. In addition, the private sector is well situated to draw on local and international experience in the waste management field and introduce proven and cost effective technologies along with management expertise 
(Cointreau-Levine and Coad, 2000; Ahmed and Ali, 2004; Ezebilo and Animasaun, 2011).

However, the sustainability and efficiencies of private sector involvement in solid waste management would depend largely on people's WTP for the improved services of these private sectors. Consequently, it is necessary to evaluate the willingness to pay for improved solid waste management services among the urban residents in Nigeria. Specifically, the study seeks to determine the perception of residents concerning the present waste management situation in Ihiala, Nigeria, as well as factors affecting WTP for improved services among the residents of the Ihiala town. This has become necessary due to the rapidly increasing population of the town, resulting from its proximity to Onitsha metropolis, and secondly as a transit town that links two major cities (Onitsha and Owerri), thus accounting for a heavy influx of people and consequently, waste generation.

\section{Materials and Methods}

Study Area

The study was conducted in Ihiala, the administrative capital of Ihiala Local

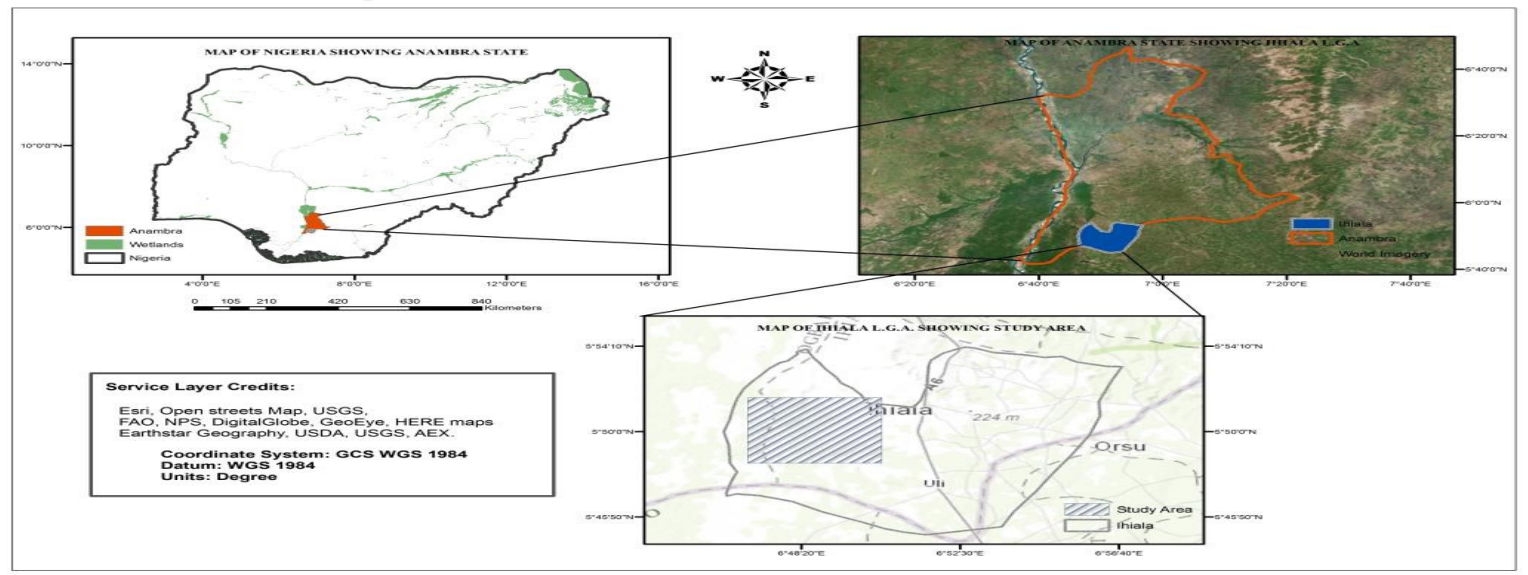

Figure 1: Map of Nigeria showing Anambra state and the study area 


\section{Study Design and Data Collection}

The study was based on primary data collected with the aid of a structured questionnaire in a cross sectional survey of households in the study area. Multistage sampling was used for the study. Four (4) districts (NITEL area, Market area, Ezego area and the Local Government block area) were randomly selected from the five districts. Five streets were chosen randomly from each of the districts; while five households were chosen systematically form each of the streets, giving a total of 100 households. Although the questions were directed to the household heads, other members of the households who could supply reliable information on the questions were interviewed especially when the household heads was unavailable. A limitation of the study is that there was no comprehensive sample frame of households available in the study area.

Efforts were made to make the sampling as scientific as possible by approximating the total number of houses in each street and selecting the five households through a systematic sampling approach. Out of the 100 questionnaires administered to the heads of selected households, ninety were found suitable for analysis. The WTP question was elicited from the respondents using the iterative bidding approach, following Randall et al. (1974) and Whittington et al. (1990), which was observed to most closely model the actual buying behaviour of the respondents in the study area. The respondents' were asked if they were willing to pay for an improvement in solid waste disposal. If the answer was positive, they were asked how much they were willing to pay for improvement in solid waste disposal due to private sector involvement. They were then probed further by increasing the bid in a follow-up question, in order to increase the accuracy of the response. Criticism that the respondents may find the question of WTP difficult to answer does not hold in this study, because the respondents are well aware of the visible deplorable state of SWD in their environment and the concept of paying is not strange, since they already pay yearly to the government for the service. Respondents that were not willing to pay were also asked for their reasons.

\section{Analytical Techniques}

Frequency tables and percentages were used to describe the socio-economic characteristics and the perception of the households about the current waste disposal system. The inferential statistical tool that was used was the ordinal logistic regression. Ordered logit is used when the dependent variable has more than two categories and the values of each category have a meaningful sequential order where a value is indeed 'higher' than the previous one. The dependent variable is the maximum WTP of the respondents, and it was categorized into six categories as shown in table 3 . This was done to further investigate the changes in the probabilities of WTP due to changes in the explanatory variables for each category of expressed WTP.The interpretation of ordered logit coefficients cannot be read as regular OLS coefficients as they are in log-odds units. The signs of the parameter estimates and statistical significance indicate the direction of the response associated with a particular variable. However, the 
changes in the probabilities associated to the categories of the dependent variable are not reported. Thus, it is necessary to estimate the category specific marginal effects which show the influence of a variable across the categories of the dependent variable. Marginal probabilities measure the change in the probability of each WTP outcome with respect to a change in each explanatory variable (Boccaletti and Nardella, 2000; Gunduz and Bayramoglu, 2011; TorresReyna, 2015).

The model is mathematically stated thus;

$\operatorname{Pr}(Y \leq j)=\ln \left(\frac{\sum \operatorname{pr}(Y \leq j \mid X)}{1-\sum \operatorname{pr}(Y \leq j \mid X)}\right)=\alpha_{j}+\beta_{1} X_{1}+\cdots+\beta_{9} X_{9}$

$\mathrm{j}=0,1,2,3,4,5$

Where:

$\mathrm{Y}=$ Maximum WTP of each respondent (categorized into 6; not willing to pay $=0, \mathrm{~N} 1$ $150=1, \mathrm{~N} 151-300=2, \mathrm{~N} 301-450=3, \mathrm{~N} 451-600=4,>\mathrm{N} 600=5$ )

$\alpha=$ threshold, $\beta_{1}-\beta_{9}=$ estimated parameters

$\mathrm{X}_{1}=$ Gender of household head (male $=1$; female $\left.=0\right)$

$\mathrm{X}_{2}=$ Marital status (married $=1$; otherwise $=0$ )

$\mathrm{X}_{3}=$ Age (in years), $\mathrm{X}_{4}=$ Household size

$\mathrm{X}_{5}=$ House type (owned $=1$; otherwise $=0$ ), $\mathrm{X}_{6}=$ Educational level (in years of formal education)

$\mathrm{X}_{7}=$ Monthly Income (in Naira)

$\mathrm{X}_{8}=$ Awareness of adverse effect of Improper SWD $($ Yes $=1 ;$ No $=0)$

$\mathrm{X}_{9}=$ Time taken to the disposal site (in minutes)

\section{Results and Discussion}

Socio-economic Characteristics of Respondents

The majority $(88.9 \%)$ of the households were headed by males, while approximately seventy three percent (73.3\%) were married with a mean household size of 5 persons. The mean age was 35.4 years, which shows that most of the respondents were still in their economic active age and can still work to earn more income which can influence their decision on whether to pay more or less for improved MSW services, while about $55.6 \%$ had secondary school education. Most of the respondents were engaged in non-formal employment
(70\%) with trading taking the biggest share $(42.2 \%)$ while their average income was approximately $\mathrm{N} 30000$ per month. Most of the respondents (57.8\%) lived in rented accommodations while the remaining 38\% lived in their houses (table 1).

\section{Waste Disposal Characteristics of Respondents}

The most common method of waste disposal in the study area was through open dumpsites $(42.2 \%)$ that are poorly managed while another $38.9 \%$ of respondents claimed that they dispose of their solid waste by burning. Although $23.3 \%$ of the respondents dispose their waste daily, majority (42.2\%) of them do 
Willingness to Pay for Improved Solid Waste Management Services................. YAWOLE et al.

so weekly. This could be a means to reduce the trip to the dumpsites and conserve time to do other activities. In addition, fifty six percent $(55.6 \%)$ of them believed their current method of SWD to be acceptable (table 2).

Table 1: Socio-Economic Characteristics of the Respondents

\begin{tabular}{|c|c|c|c|c|c|}
\hline VARIABLES & FREQUENCY & PERCENTAGE & MINIMUM & MAXIMUM & MEAN \\
\hline \multicolumn{6}{|l|}{$\begin{array}{l}\text { Gender of } \\
\text { Household Head }\end{array}$} \\
\hline Male $=1$ & 80 & 88.9 & & & \\
\hline Female $=0$ & 10 & 11.1 & & & \\
\hline \multicolumn{6}{|l|}{ Marital Status } \\
\hline Otherwise $=0$ & 24 & 26.7 & & & \\
\hline Married=1 & 66 & 73.3 & & & \\
\hline Age range & & & 19 & 70 & 35.4 \\
\hline$<30$ & 37 & 41.1 & & & \\
\hline $31-40$ & 27 & 30.0 & & & \\
\hline $41-50$ & 22 & 24.4 & & & \\
\hline $51-60$ & 3 & 3.3 & & & \\
\hline$>60$ & 1 & 1.1 & & & \\
\hline Household size & & & 1 & 20 & 4.84 \\
\hline$<2$ & 19 & 21.1 & & & \\
\hline $3-5$ & 39 & 43.3 & & & \\
\hline $6-9$ & 29 & 32.2 & & & \\
\hline$>9$ & 3 & 3.3 & & & \\
\hline \multicolumn{6}{|l|}{ House type } \\
\hline Otherwise $=0$ & 52 & 57.8 & & & \\
\hline Owned=1 & 38 & 42.2 & & & \\
\hline Educational Level & & & 6 & 18 & 12.13 \\
\hline No education & 0 & 0.0 & & & \\
\hline Primary School & 14 & 15.6 & & & \\
\hline Secondary school & 50 & 55.6 & & & \\
\hline NCE/OND & 8 & 8.9 & & & \\
\hline HND/BSc & 17 & 18.9 & & & \\
\hline MSc/PhD & 1 & 1.1 & & & \\
\hline \multicolumn{6}{|l|}{ Occupation } \\
\hline Civil service & 21 & 23.3 & & & \\
\hline Trader & 38 & 42.2 & & & \\
\hline Artisan & 24 & 26.7 & & & \\
\hline Private Salaried job & 6 & 6.7 & & & \\
\hline Farming & 1 & 1.1 & & & \\
\hline Monthly Income & & & 1500 & 100000 & 29594.4 \\
\hline$<20000$ & 39 & 43.3 & & & \\
\hline $20001-40000$ & 34 & 37.8 & & & \\
\hline $40001-60000$ & 9 & 10.0 & & & \\
\hline $60001-80000$ & 5 & 5.6 & & & \\
\hline$>80000$ & 3 & 3.3 & & & \\
\hline
\end{tabular}


Table 2: Waste Disposal Characteristics of Respondents

\begin{tabular}{|c|c|c|}
\hline VARIABLES & FREQUENCY & PERCENTAGE \\
\hline \multicolumn{3}{|l|}{ Current method of SWD } \\
\hline Nearby Dumpsite & 38 & 42.2 \\
\hline Burning & 35 & 38.9 \\
\hline Informal Waste vendor & 13 & 14.4 \\
\hline Indiscriminate bush throwing & 4 & 4.4 \\
\hline \multicolumn{3}{|l|}{ Frequency of waste disposal } \\
\hline Daily & 21 & 23.3 \\
\hline Bi-weekly & 22 & 24.4 \\
\hline Weekly & 38 & 42.2 \\
\hline Fortnightly & 1 & 1.1 \\
\hline Monthly & 8 & 8.9 \\
\hline \multicolumn{3}{|c|}{ Reliability of current method of SWD } \\
\hline Excellent & 11 & 12.2 \\
\hline Good & 50 & 55.6 \\
\hline Indifferent & 8 & 8.9 \\
\hline $\mathrm{Bad}$ & 16 & 17.8 \\
\hline Very bad & 5 & 5.6 \\
\hline \multicolumn{3}{|c|}{ Table 3: Awareness and Response to WTP } \\
\hline VARIABLES & FREQUENCY & PERCENTAGE \\
\hline \multicolumn{3}{|c|}{ Awareness of adverse effect of improper SWD } \\
\hline Yes & 83 & 92.2 \\
\hline No & 7 & 7.8 \\
\hline \multicolumn{3}{|l|}{ Willingness to pay } \\
\hline Yes & 58 & 64.4 \\
\hline No & 32 & 35.6 \\
\hline \multicolumn{3}{|l|}{ Reason for unwillingness to pay } \\
\hline Current method of SWD is good & 11 & 12.2 \\
\hline Responsibility of the government & 6 & 6.7 \\
\hline No financial capacity & 15 & 16.7 \\
\hline \multicolumn{3}{|l|}{ Distribution of WTP responses } \\
\hline Not willing to pay $(\mathrm{WTP}=0)$ & 32 & 35.6 \\
\hline $\mathrm{N} 1-150(\mathrm{WTP}=1)$ & 8 & 8.9 \\
\hline N151-300 (WTP=2) & 30 & 33.3 \\
\hline N300-450 (WTP=3) & 4 & 4.4 \\
\hline $\mathrm{N} 450-600(\mathrm{WTP}=4)$ & 11 & 12.2 \\
\hline$>\mathrm{N} 600(\mathrm{WTP}=5)$ & 5 & 5.6 \\
\hline
\end{tabular}

Awareness of Adverse Effects of Improper SWD and Willingness to Pay

Most (92.2\%) of the respondents were aware of the various adverse effects of improper solid waste management.
However, when the willingness to pay for improved SWD services was posed to the respondents, $64.4 \%$ were willing to pay for private sector involvement while $35.6 \%$ were unwilling to pay at all. The 
Willingness to Pay for Improved Solid Waste Management Services.................YAWOLE et al.

reasons given by those not willing to pay were lack of financial capacity, belief that the current method they employ is still acceptable and that solid waste management is essentially the responsibility of the government. This reason was also reported by Ezebilo and Animashaun (2011) in the southwestern part of Nigeria (table 3 ).

\section{Determinants of WTP for Improved Solid Waste Management}

The results of the ordered logit model and summary statistics are presented in table 4. It shows that marital status and household size have a positive and significant influence on WTP, suggesting that respondents who are married and have more household members are more likely to be willing to pay for improved SWD services. This may be as a result of the fact that married households generally tend to generate more waste, and are likely to be more affected by inefficient waste disposal services, and thus, be more favourably disposed to pay more for its efficient disposal. This view is also held by Basili et al. (2005) and Hagos et al. (2012), who found out the same in Ethiopia. Income has a positive and significant effect on households' WTP. This suggests that people who have more income have a higher probability to pay for improved SWD services. A reason may be that people with more money may place more value on their health as well as the aesthetic quality of their environment which individuals with less income may not consider as a necessity. This view is well supported in literature by Rahji and Oloruntoba (2009), Ezebilo and Animashaun (2011), as well as Khattak and Amin (2013).

The marginal probabilities for the six WTP categories are presented in table 5 . The marginal effects of each explanatory variable must sum to zero across the six WTP categories. This is because the probabilities for the WTP categories must sum to one, therefore, the change in probabilities for the WTP categories must sum to zero (Cranfield and Magnusson, 2003). The results show that being married reduces the probability of being unwilling to pay for private sector involvement in solid waste management $(\mathrm{WTP}=0)$ and the probability of being willing to pay the lowest amount possible $(\mathrm{WTP}=1)$, relative to unmarried respondents. However, being married increases the probability of WTP for the other categories of WTP; the probability of paying between $\mathrm{N} 450-\mathrm{N} 600(\mathrm{WTP}=4)$ and more than N600 (WTP=5) increased by 0.15 and 0.08 percentage points respectively. Household size also follows the same trend observed above. As household size increases, the probabilities for the first two WTP categories reduce, while the probabilities of higher categories of WTP increase with household size. Having more income also decreases the probability of being unwilling to pay and willing to pay the lowest category of WTP (N1-N150), and increases the probability of being WTP in all the higher categories of WTP. Interestingly, the education variable suggests that respondents with more years of education have less probability of WTP, although not significant. 
Table 4: Determinants of WTP for Improved MSW Services (ordered logit)

\begin{tabular}{|c|c|c|c|c|c|c|}
\hline \multicolumn{2}{|l|}{ VARIABLES } & \multicolumn{2}{|c|}{ COEFFICIENT } & Z-Statistics & \multicolumn{2}{|c|}{ Probability } \\
\hline \multicolumn{2}{|c|}{ Gender of Household Head } & \multicolumn{2}{|c|}{0.72603} & 0.78 & \multicolumn{2}{|c|}{0.437} \\
\hline \multicolumn{2}{|c|}{ Marital status } & \multicolumn{2}{|l|}{1.45839} & $2.63 * * *$ & \multicolumn{2}{|c|}{0.009} \\
\hline \multicolumn{2}{|l|}{ Household Size } & \multicolumn{2}{|l|}{0.14451} & $2.47 * *$ & \multicolumn{2}{|c|}{0.013} \\
\hline \multicolumn{2}{|l|}{ House type } & \multicolumn{2}{|l|}{-0.29115} & -0.64 & \multicolumn{2}{|c|}{0.519} \\
\hline \multicolumn{2}{|l|}{ Income } & \multicolumn{2}{|l|}{0.00003} & $2.68 * * *$ & \multicolumn{2}{|c|}{0.007} \\
\hline \multicolumn{2}{|c|}{ Time taken to disposal site } & \multicolumn{2}{|l|}{-0.15656} & -0.37 & \multicolumn{2}{|c|}{0.713} \\
\hline \multicolumn{2}{|c|}{ Awareness of adverse effect of ISWD } & \multicolumn{2}{|l|}{-0.36296} & -0.53 & \multicolumn{2}{|c|}{0.597} \\
\hline \multicolumn{2}{|c|}{ Educational level } & \multicolumn{2}{|l|}{-0.05543} & -0.82 & 0.410 & \\
\hline $\begin{array}{l}\text { Age } \\
\text { Prob }>\text { chi }^{2}=0.036 \\
\text { Log likelihood }=-127.1 \\
\text { Pseudo } \mathrm{R}^{2}=0.060\end{array}$ & & -0.02426 & & -0.91 & 0.361 & \\
\hline *Significant at $10 \%$ & *Significant & $5 \%$ & Significant & th at $1 \%$ & & \\
\hline Variables & $\begin{array}{l}\text { Prob } \\
(\mathrm{WTP}=0)\end{array}$ & $\begin{array}{l}\text { Prob } \\
(\mathrm{WTP}=1)\end{array}$ & $\begin{array}{l}\text { Prob } \\
(\mathrm{WTP}=2)\end{array}$ & $\begin{array}{l}\text { Prob } \\
(\mathrm{WTP}=3)\end{array}$ & $\begin{array}{l}\text { Prob } \\
(\mathrm{WTP}=4)\end{array}$ & $\begin{array}{l}\text { Prob } \\
(\mathrm{WTP}=5)\end{array}$ \\
\hline $\begin{array}{l}\text { Gender of Household } \\
\text { Head }\end{array}$ & -0.1735 & -0.0059 & 0.0836 & 0.0190 & 0.0543 & 0.0224 \\
\hline Marital status & -0.2821 & -0.0430 & 0.0513 & 0.0389 & 0.1519 & 0.0829 \\
\hline Household Size & -0.0324 & -0.0031 & 0.0128 & 0.0041 & 0.0129 & 0.0057 \\
\hline House type & 0.0658 & 0.0060 & -0.0265 & -0.0083 & -0.0256 & -0.0112 \\
\hline Income & $-7.83 e-06$ & $-7.64 e-07$ & $3.09 \mathrm{e}-06$ & $1.01 \mathrm{e}-06$ & $3.12 \mathrm{e}-06$ & $1.38 \mathrm{e}-06$ \\
\hline $\begin{array}{l}\text { Time taken to disposal } \\
\text { site }\end{array}$ & 0.0035 & 0.0003 & -0.0013 & -0.0004 & -0.0014 & -0.0006 \\
\hline $\begin{array}{l}\text { Awareness of adverse } \\
\text { effect of ISWD }\end{array}$ & 0.0771 & 0.0100 & -0.0246 & -0.0106 & -0.0354 & -0.0165 \\
\hline Educational level & 0.0124 & 0.0012 & -0.0049 & -0.0015 & -0.0049 & -0.0021 \\
\hline Age & 0.0054 & 0.0005 & -0.0021 & -0.0007 & -0.0021 & -0.0009 \\
\hline
\end{tabular}

\section{Conclusion and Recommendations}

The study used primary data to analyze the willingness to pay for improved solid waste management as well as the factors influencing the choice of residents in the study area. Majority of the residents were aware of the inherent risks that could stem out of improper solid waste management, although a lesser proportion of them were willing to pay for an improvement, since they believed that it is a responsibility owed them by the government. The results showed that marital status, household size and income are factors that influence WTP among the residents. The study recommends that the government place priority on the promulgation and implementation of policies geared towards a more efficient SWM system as solid waste management is still largely a government responsibility and also, initiate policies that are favourable to potential investors, towards an effective public-private partnership. In addition, it was observed that residents with higher 
income had a higher probability to be willing to pay. Thus, WTP can be enhanced through policies designed towards improving the incomes of residents. Furthermore, awareness campaigns designed to encourage the citizens about their civic responsibilities towards the sustainable use of the environment should also be carried out.

\section{References}

Ahmed, S.A. and Ali, M. (2004). Partnerships for waste management in developing countries: linking theories to realities. Habitat International, 28(3): 467-479.

Aiyeloja, A.A., Oladele, A.T. and Ezeugo, O.E. (2012) Evaluation of non-timber forest Products trade in Ihiala local government area, Anambra state, Nigeria. International Journal of Science and Nature. 3(2): 366-372

Alabi, M. (2004). Waste Products Survey for Identification and Quantification Of Different Wastes generated In Nigeria. An Unpublished PhD Thesis in the Department of Geography, University of Ibadan

Asase, M., Yanful, E.K., Mensah, M., Stanford, J. and Amponsah, S. (2009). Comparison of municipal solid waste management systems in Canada and Ghana: a case study of the cities of London, Ontario, and Kumasi, Ghana. Waste Management 29(10):2779-2786.

Basili, M., Di Matteo, M. and Ferrini, S. (2005). Analysing demand for environmental quality: A willingness to pay/accept study in the province of Siena (Italy). Waste Management, 26: 209-219
Boccaletti, S. and Nardella, M. (2000). Consumer Willingness to Pay for Pesticide-free Fresh Fruit and Vegetables in Italy. International Food and Agribusiness Management Review, 3: 297-310.

CASSAD (Centre for African Settlement Studies and Development) (1998). Workshop on Turning Waste to Wealth-Strategies, Options, Appropriate and Affordable Technology for Waste Management, Training Module Prepared Course Codes CASTWW/98 April

Chukwu, K.E. (2010). Effects of Enugu Urban Environment on the Water Quality of Streams in Nyaba Catchment Area of south Eastern Nigeria. Unpublished Ph.D Thesis. University of Nigeria, Nsukka.

Cointreaus-Levine, S. (1994). Private Sector Participation in Municipal Solid Waste Services in Developing Countries Volume 1. The Formal Sector.Published for Urban.ManagementProgramme.Th e World Bank, Washington, D.C.

Cointreau-Levine, S. and Adrian Coad (2000). Guidance Pack: Private sector participation in municipal solid waste management. Swiss Centre for Development Cooperation in Technology and Management.

http://www.worldbank.org/urban/so lid_wm/erm/CWG\%20folder/guida ncepack_part1.pdf

Cranfield J.A.L. and Magnusson, E. (2003). Canadian Consumer's Willingness-To-Pay For Pesticide Free Food Products: An Ordered Probit Analysis. International Food 
and Agribusiness Management Review, 6(4): 13-30.

Ezebilo, E.E. and Animashaun, E.D. (2011). Economic Valuation of Private Sector Waste Management Services. Journal of Sustainable Development, 4(4): 38-46

Gunduz, O. and Bayramoglu, Z. (2011) Consumers' willingness to pay for organic chicken meat in Samsun province of Turkey.Journal of Animal and Veterinary Advances, 10(3)334-340.

Hagos, D., Mekonnen, A. and Gebreegziabher, Z. (2012). Households' Willingness to Pay for Improved Urban Waste Management in Mekelle City, Ethiopia. Environment for Development: Discussion Paper Series EfDDP 12-06

Khattak, N. and Amin, S. (2013). Willingness to Pay for the Treatment of Environmental Hazards: A Case Study Of Peshawar. Asian Economic and Financial Review, 3(7): 831-842

Momodu, N.S., Dimuna, O.K. and Dimuna, J.E. (2011). Mitigating the impact of solid wastes in urban centres in Nigeria.Journal of Human Ecology, 34(2): 125-133

Rahji, M.A.Y. and Oloruntoba, E.O. (2009). Determinants of household willingness to pay for private solid waste management services in Ibadan, Nigeria.Waste Management and Research, 27(10): 961-965.

Salau, A.T. (1992). Global Environmental Change: A Research Agenda for Africa. CODESRIA Working Paper 2; 49 pp.

Torres-Reyna, O. Getting Started in Logit and Ordered Logit Regression. Data and statistical services, Princeton University http://dss.princeton.edu/training/

UNEP (2005). Solid Waste Management.CalRecovery Incorporated Volume 1

Whittington, D., Briscoe, J., Mu, X. and Barron, W. (1990). Estimating the willingness to pay for water services in developing countries: A case study of the use of contingent valuation surveys in Southern Haiti. Economic Development and Cultural Change,pp 293-311.

Yusuf, S.A., Ojo, O.T. and Salimonu, K.K. (2007). Households' Willingness to pay for improved household solid waste management in Ibadan -North LGA of Oyo State, Nigeria. Journal of Environmental Extension University of Ibadan, 6: 57-63. 